\title{
Agronomic Characterization of yam genotypes production
}

\author{
Sandra Domingos João Afonso ${ }^{(1)(2)}$, Ricardo Franco Cunha Moreira ${ }^{(1)}$, Antonio \\ Leandro da Silva Conceição ${ }^{(1)}$, Simone Alves Silva ${ }^{(1)}$ \\ (1) Federal Universityof Bahia Recôncavo, CenterofAgriculturalSciences, EnviromentalandBiological, Rua Rui \\ Barbosa 710, Centro - University Campus, CEP 44380-000, Cruz das Almas, Bahia, Brazil. \\ ${ }^{(2)}$ Research Assistant at the Polytechnic Institute of Kwanza Sul, Street November 12th, Center, Kwanza-Sul \\ Angola
}

\begin{abstract}
Data from three agronomic traits were used to assess the genetic dissimilarity between 209 yam (Dioscorea sp.)genotypes. The data were analyzed using the method of nearest neighborand the technique of grouping throughanalysis of variances using the distance Mahalanobis generalized as dissimilarity measure. The genotypes tested were four distinct groups by grouping. The character width of tubercle contributed the most to thetotal genetic dissimilarity. The results allowed to discriminate genotypes that could be used in the genetic breeding programs for the species.
\end{abstract}

Terms for indexing:Dioscorea spp., multivariate analysis, grouping methods

\section{Introduction}

Yam belongs to the family Dioscoreaceae and the genus Dioscorea, which has more than 600 species, 14 of which have their tubers used as food. The main species cultivated in Brazil are D. alata,with the types Cará São Tomé e Principe, Cará Cassava, Cará Florida, followed by D. cayanensis, with various types such as Cará Tabica, Cará Negro, Cará Costa mainly planted in the region Recôncavo da Bahia, the third largest national producer (MESQUITA, 2001), as a promising alternative for the small and medium-sized producers of this State, due to its great potential for exporting and domestic consumption as high nutritional quality food.

According to Scarcelliet. al.,(2006),yam is the second most importanttuber crop in Africa after cassava.Therefore, West African farmers produce more than $90 \%$ of the world's yams (FAOSTAT 2003).

Yamis a tuberous species with high potential rich in vitamin B complex, (containing high levels of thiamine, riboflavin, niacin), vitamin A, ascorbic acid, carbohydrates and starch grains (responsible for high digestibility), constituting an essential foodfor the population, and may also be used in agribusiness (SANTOS et al. , 1998; SANTOS\&MACEDO, 2002).It's spread is made of vegetative form, with tubers seeds cut into pieces of approximately $200 \mathrm{~g}$, planted on ridgeswith $0.50 \mathrm{~m}$ of height and spacing of $1.20 \mathrm{~m}$ between ridges and $0.40 \mathrm{~m}$ between plants. The majority of producers in the region Recôncavo uses organic fertilizer in fertilizing the crop and the staking system in rods for the driving of the plants.

In spite of the importance of culture for the agribusiness northeastern, your productivity $(11,093 \mathrm{~kg}$ ha${ }^{1}$ ) (SANTOS, 2006) is still low, due to the inadequate conditions of crop management, soil fertility, use of tubers seeds of lower quality and phytosanitary problems.

In spite of Yam genotypes great plasticity and adaptability to tropical climates, it is necessary to characterize and assess them, using agronomic traits, in order to provide options of right attributes for the program to improve the species as well as preserve part of their variability ex situ. In these circumstances, multivariate techniques appear to beefficient in the description and selection of multiple characters simultaneously, thus saving time and financial resources (CRUZ, 1990). The data generated will be relevant in programs for identification of useful phenotypic characters, enabling the development of technologies and generation of basic knowledge for thesupport and operationof this crop and assist in genetic/breeding programs of the species.

The objective of this study was to evaluate the yield and characterize the agronomic potential of yam genotypes from Recôncavo of Bahia.

\section{Material and methods}

209 commercial access were used (Table 1), which are from São Felipe and Cruz das Almas. The distinction between the various genotypes was made by visual comparison wherein the studied characters relate to underground part of the plant. Three descriptorswere used to characterizethe genotypes: length of tuber - CT; width of tuber - LT and weight of tuber - PT. All measures for morphological descriptions were done according to the International Plant Genetic Resources Institute and International Institute of Tropical Agriculture (IPGRI, 1997). 
Table 1. Identification of 209 accessions of yam, from Recôncavo Baiano, used in the study.

\begin{tabular}{llc}
\hline Origin & Locationofcollection & Numberofgenotypes \\
\hline Bom Gosto, São Felipe & Rural property & 124 \\
Sapucaia, Cruz das Almas & Rural property & 40 \\
Sanca, Cruz das Almas & Rural property & 30 \\
Cadete, Cruz das Almas & Rural property & 15 \\
\hline Total & & 209 \\
\hline
\end{tabular}

The statistical analyzes were performed using the program GENES (CRUZ, 2006) and on average, applied the test of Scott Knott at a $\mathrm{p} \leq 0.05$ level. The cluster analysis was done as proposed and described bySneath\&Sokal (1973), using the generalized Mahalanobis distance as a coefficient of similarity/dissimilarity between pairs of locations; hence the smaller the distance between two locations, the more similar they are. The average linkage UPGMA (Unweighted Pair Group Method with Arithmetic Averages) was adopted for grouping the genotypes.

\section{Results and Discussion}

There were significant differences at $\mathrm{p} \leq 0.05$ levelregarding all traits(Table 2 ), suggesting variability among the genotypes. The Table 2 shows the comparison of means of the traits. The differences between the genotypes showed variability for the traits. The coefficients of variation ranged from $32.01 \%$ (width of tubercle) to $79.75 \%$ (weight of tuber). The yield of marketable tubers is the main objective of a commercial exploitation of yam.

However, there was a wide variation regarding the weight of tuber, suggesting that there is a significant genotype $\mathrm{x}$ environment interaction. There was also a wide variation as a result of the differences in local and growing seasons, in addition to different management practices that were adopted (PEREIRA et al. 2003). In relation to yam materials, the variation could be explained by the accessions from different regions, and the management system employed by traditional farmers, through the introduction or exchange of materials within and between communities (MOREIRA et al. 2007), thus causing, representativeness variable of variability.

Table 2. ANOVA for univariate characters in 209 yam genotypes.

\begin{tabular}{|c|c|c|c|c|}
\hline \multirow[b]{2}{*}{ Characters } & \multicolumn{2}{|c|}{ AverageSquare } & \multirow[b]{2}{*}{ Average } & \multirow{2}{*}{$\begin{array}{l}\text { CV } \\
(\%)\end{array}$} \\
\hline & Access & Error & & \\
\hline Lengthoftuber & $622.53^{x x}$ & 128.8 & 33.01 & 34.37 \\
\hline Widthoftuber & $4026.89^{x \times}$ & 668.84 & 80.77 & 32.01 \\
\hline Weightoftuber & $7.27^{\times x}$ & 1.35 & 1.46 & 79.75 \\
\hline
\end{tabular}

*** Significant at $\mathrm{p} \leq 0.05$ levelusing the $\mathrm{F}$ test.

The relative contribution of each character to the genetic dissimilarity observed in Table 3, allows you to identify the character width of the tuber was efficient in explaining the genetic dissimilarity between the 209 genotypes of yam evaluated, contributing with $43.93 \%$ for the total dissimilarity, indicating that this should be prioritized in the choice in breeding programs followed by the character weight of tuber. The character length of the tuber presented estimate ofS. j (method proposed by Singh, 1981)of small magnitude, not revealing, therefore, of great importance for the evaluation of dissimilarity. Taken together, these characteristics are important and will define the marketing.

The size of the tuber is an important factor in the definition of the consumer market. According to Santos (1996), the tubers weighing between 0.70 and $1.50 \mathrm{~kg}$ are destined to USA markets; 1.60 to $2.00 \mathrm{~kg}$ exported to France and between 2.10 and $3.00 \mathrm{~kg}$ to other European markets, while those with more than $3 \mathrm{~kg}$ are the non-exportable type, reaching low prices. Thus, it important to identify the factors responsible for these large tubers, in order to prioritize the exportable type, which could bring better incomes to the farmer. Probably some of these factors could be the type and quantity of fertilizer used in the management of the culture, as well as the use of irrigation.

Table 3. Relative Contribution of length characters of the tuber, width of tuber weight and tuber for the genetic dissimilarity of 209 genotypes of yam.

\begin{tabular}{lccc}
\hline & \multicolumn{3}{c}{ Genetic dissimilarity } \\
\cline { 2 - 4 } Charactersevaluated & S.j & \% & \% Accumulated \\
\hline Lengthoftuber & 18.66 & 17.69 & 17.69 \\
Widthoftuber & 46.35 & 43.93 & 61.62 \\
Weightoftuber & 40.48 & 38.37 & 100.00 \\
\hline
\end{tabular}

S.j - method proposed by Singh, 1981 
The grouping criteria adopted by hierarchical method nearest neighbor, represented in Figure 1, establishes that it is initially formed a group of similar genotypes, and the distances of the other are calculated in relation to groups formed (CRUZ \& REGAZZI, 1997). By this technique, the genotypes from areas one and two (BomGosto, São Felipe) were the least distance, and the greatest distance in relation to the other was assigned to the genotypes from area eight (Cadete, Cruz das Almas). The distance of the genotypes of area eight, in relation to the other genotypes, suggests that these can be used with success in breeding program for the species.

Table 4 shows the variances (eigenvectors), the percentage variances and variances accumulated of canonical variables of the 10 established groups. Due to the fact that the first two canonical variables explained more than $90 \%$ of the total variance in the whole set of characters $(99,86 \%$ of the total variance accumulated), it could possibly explain the variability manifested among the genotypes and, therefore, allowing an interpretation of the phenomenon with simplification as in a two-dimensional scatterplot (CRUZ, 1987; CRUZ \& REGAZZI, 1997) (Figure 2).

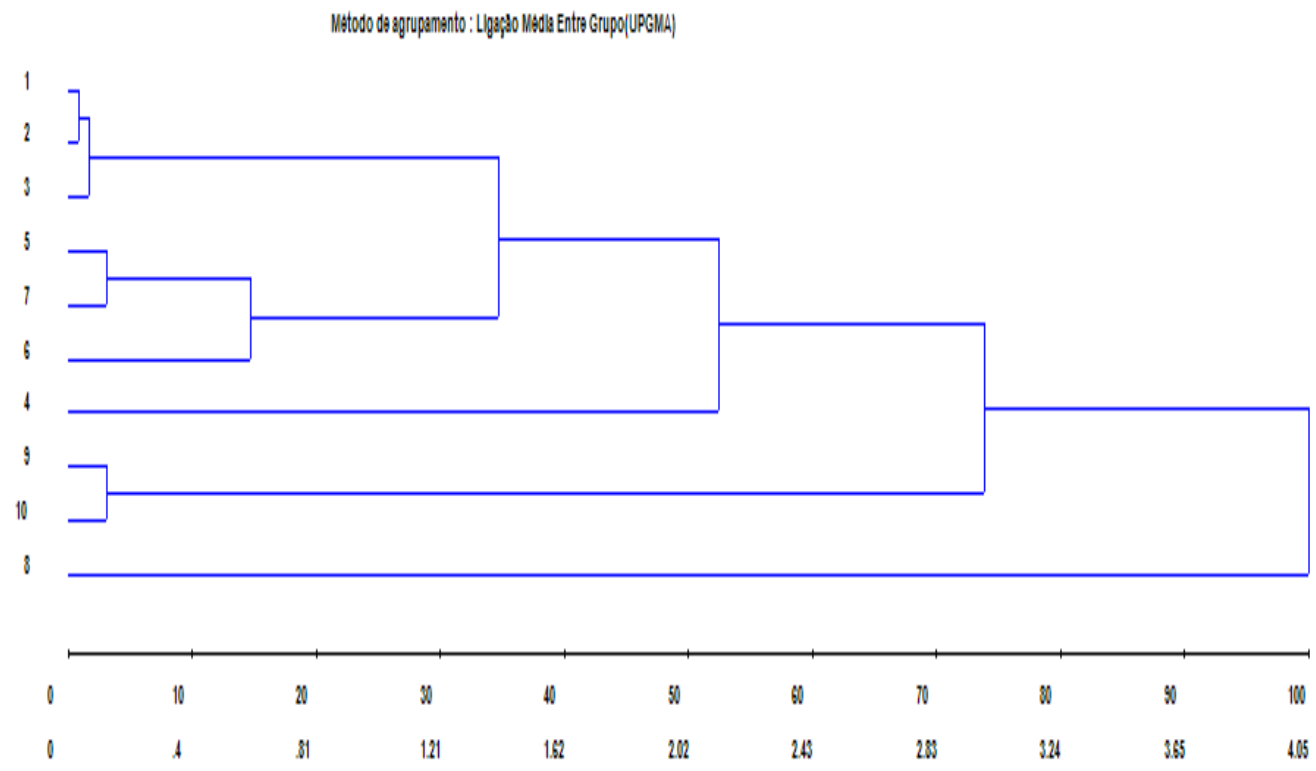

Figure 1.Dendrogram representing the genetic dissimilarity between the 209 genotypes studied, obtained by the technique of the nearest neighbor, using the distance Mahalanobis generalized as dissimilarity measure.

Table 4. Variance (eigenvalues), percentage variances and variances accumulated of canonical variables, aiming to estimate the dissimilarity between 209 genotypes of yam.

\begin{tabular}{lccc}
\hline Variable & Variances(eigenvalues) & $\begin{array}{c}\text { Variances } \\
\text { percentage }\end{array}$ & $\begin{array}{c}\text { Variances } \\
\text { Accumulated }(\%)\end{array}$ \\
\hline Lengthoftuber & 345.71 & 93.02 & 93.02 \\
Widthoftuber & 25.43 & 6.84 & 99.86 \\
Weightoftuber & 0.5 & 0.13 & 100 \\
\hline
\end{tabular}

The technique of principal components scattered 209 genotypes established by distance of dissimilarity in four different groups. The similar and dissimilar groups showed equivalent distances between themselvesthat can be represented in a 2-dimensional plane. The separation of these groups in the graph is dependent on the scale, showing the subjectivity of this type of analysis of genetic dissimilarity as noted by Cruz (1990). 


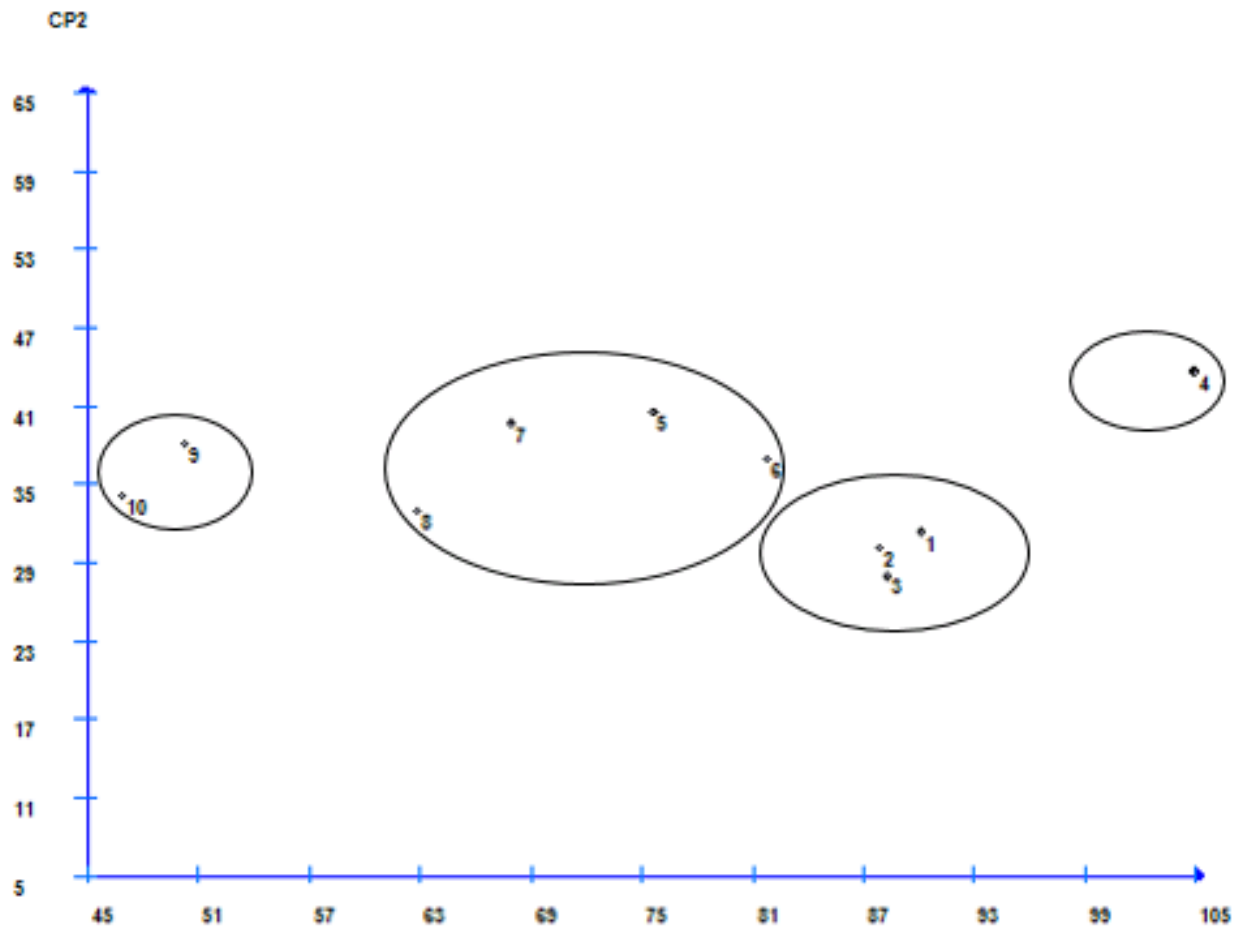

Figure 2. Graphical Dispersion of scores of canonical variable 1 (CP1) and the canonical variable 2 (CP2) on the 4 groups established by the method of grouping the nearest neighbor.

The techniques employed in this study will be useful in genetic improvement programs of culture of yam Recôncavo Baiano region aiming at obtaining promising genotypes, by presenting greater genetic divergence between themselves, as well as to serve as guidance in the choice of populations most appropriate to apply methods of mass selection.

\section{Conclusions}

The character width of the tuber was contributed the most to the genetic dissimilarity between total 209 genotypes of yam analyzed. The presence of variability allowed identification of dissimilar genotypes, with the formation of four groups.

\section{Acknowledgments}

We would like to thank all the farmers who joined in this proposal and the partner institutions by resources that generate the present work as the Research Support Foundation of the State of Bahia, by granting Postdoctoral fellowship to the second author and Bank of Northeast ofBrazil, by financial support of the research.

\section{References}

[1]. CRUZ, C.D. Programa Genes: Análise multivariada e simulação. Editora UFV. Viçosa (MG). 175 p. 2006

[2]. CRUZ, C.D. Algumas técnicas de análise multivariada no melhoramento de plantas. Piracicaba: ESALQ, 1987. 75p.

[3]. CRUZ, C.D. Aplicação de algumas técnicas multivariadas no melhoramento de plantas. Piracicaba, 1990.188 p. Tese (Doutorado em Genética e Melhoramento). Escola Superior de Agricultura Luiz de Queiroz/ Universidade de São Paulo.

[4]. CRUZ, C.D;. REGAZZI, A.J. Divergência genética In: CRUZ, CD.; REGAZZI, A.J. Métodos biométricos aplicados ao melhoramento genético. Viçosa, UFV: Imprensa Universitária, 1997. cap. 6, p.287-324.

[5]. FAOSTAT 2003. http://faostat.fao.org/default.jsp.

[6]. INTERNATIONAL PLANT GENETIC RESOURCES INSTITUTE E INTERNATIONAL INSTITUTE OF TROPICAL AGRICULTURE. 1997. Descriptors for yam (Dioscoreaspp.).Rome, Italy. 61p.

[7]. MESQUITA, A. S. Inhame na Bahia: a produção a caminho da competitividade. Bahia Agrícola, Salvador, v.4, n.2, p.39-48, nov.2001.

[8]. MOREIRA, R. F. C.; SILVA, S. A.; ADILSON NUNES DA SILVA, A. N. DA.; MARIANA SOUZA DA SILVA, M. S. DA.; CERQUEIRA, L. S.; SOUSA, C. DA S.; SAMPAIO FILHO, O. M. Descritores práticos para caracterização botânica de genótipos de inhame no Recôncavo baiano. In: I Simpósio Baiano de Educação Ambiental, UFRB, Cruz das Almas, Bahia. 2007. 
[9]. PEREIRA, F. H. F.; PUIATTI, M.; MIRANDA, G. V.; SILVA, D. J.H.da.; FINGER, F. L. Caracterização agronômica da produção de rizomas de clones de taro. Hortic. Brás., v.21, p.99-105, 2003.

[10]. SANTOS, E. S. dos. Inhame (Dioscoreaspp): aspectos básicos da cultura. João Pessoa: EMEPA-PB, SEBRAE, 1996. 158p.

[11]. SANTOS, E. S. dos. Manejo sustentável da cultura do inhame (Dioscoreasp.) no Nordeste do Brasil. Disponível em: <http://www.emepa.org.br/inhame_manejo.php>. Acesso em: 30 de agosto de 2008.

[12]. SANTOS, E. S. dos; MACÊDO, L. de S. Tendências e pespectivas da cultura do inhame (Dioscoreasp.) no Nordeste do Brasil. In: II SIMPÓSIO NACIONAL SOBRE AS CULTURAS DO INHAME E DO TARO. Anais. João Pessoa, PB: EMEPA-PB, 2002. p. 21-31.

[13]. SANTOS, E. S. dos; MACÊDO, L. de S.; MATIAS, E. C.; MELO, A. S. de. Contribuição tecnológica para a cultura do inhame no Estado da Paraíba. João pessoa, PB: EMEPAPB/MMA-PRONAF, 1998. 84p. (EMEPA-PB. Documentos, 23)

[14]. SCARCELLI, N.;TOSTAIN, S.;MARIAC, C.;AGBANGLA , C.;DA , O.;BERTHAUD, J.; PHAM. J. L.;Genetic nature of yams (Dioscorea sp.) domesticated by farmers in Benin(West Africa), 2006. p. 121-130.

[15]. SNEATH, P.H.A.; SOKAL, R.R. Numerical taxonomy: the principles and practice of numerical classification. San Francisco: W. H. Freeman, 1973. 573p. 